\title{
Evaluation Of Effects Of Nano-Silica And Crumb Rubber Powder Application To Pavement Sub Grade Soil Stabilization
}

\author{
A. K. Sutariya ${ }^{1}$, Prof.(Dr).H.R.Varia ${ }^{2}$, \\ Transportation Engineering ${ }^{1}$, Tatva Institute of Technological Studies, Modasa ${ }^{1}$ \\ Civil Engineering ${ }^{2}$, Adani Institute of Infrastructure Engineering, Ahmedabad ${ }^{2}$ \\ Email: akshaykumarsutariya@gmail.com ${ }^{1}$,hr7varia@yahoo.com ${ }^{2}$
}

\begin{abstract}
In this investigation study, at first the examination of selected weak soil will be done to evaluate the physical and engineering properties as demonstrated by Indian Standard (IS): 1498 - 1970. To assess the modification in properties of weak soil using nano silica and waste crumb rubber powder as a part of dosages as stabilizers, several laboratory tests will be planned. These additives may improve the properties of weak subgrade soil, which will be used for flexible pavement, to diminish the thickness of it from economy perspective without trade off with quality. The California Bearing Ratio (CBR) tests are considered for untreated and treated soils with ideal dosages and the readings will be recorded for 4 days.
\end{abstract}

Index Terms- Nano-silica, Crumb rubber Powder, MDD, OMC and CBR.

\section{INTRODUCTION}

In India, Black cotton soils are inorganic clays of medium to high compressibility and form a major soil. They are characterized by high shrinkage and swelling properties. This Black cotton soil occurs mostly in the central and western parts and covers approximately $20 \%$ of the total area of India. Because of its high swelling and shrinkage characteristics, the Black cotton soil has been a challenge to the highway engineers. The Black cotton soil is very hard when dry, but loses its strength completely when in wet condition. It is observed that on drying, the Black cotton develops cracks of varying depth. The growing usage of motor vehicles has not only caused the air pollution, noise pollution etc. but has also created the problem of discarding the tyres. Every year, over one billion tyres are manufactured worldwide and equal numbers of tyres are permanently removed from the vehicles, becoming waste. The U.S. is the largest producer of waste tyres, about 290 million a year, although increases in new vehicles sale in India and china are rapidly contributing to waste tyre volumes. India's waste tyres account for about 6-7\% of the global total.

\section{LITERATURE REVIEW}

Yadav and Tiwari carried out CBR test using the CRP of size range $0.8 \mathrm{~mm}-2 \mathrm{~mm}$ and concluded that CBR value decreases on increasing the percentage of CRP in soil (J.S. Yadav, 2017).

Kokila et al used the crumb rubber powder with incorporation of lime in it and concluded that CBR value increases with increase in percentage of CRP at constant proportion of lime at 3\%. Soil stabilization with rubber crumbs along with lime is more suitable for shallow foundation (Ms.L.Kokila, 2017). Prasad et al used the CRP of size $1.18 \mathrm{~mm}$ and concluded that $\mathrm{CBR}$ value increased when the optimum mix (B.C soil $+7 \%$ of CRP) was blended with cement (B. Sri Vasavi, 2016). Shrivastava et al noted that instead of fine fraction $(2.0 \mathrm{~mm}$ to $0.075 \mathrm{~mm})$ replacement with coarse fraction $(4.75-2 \mathrm{~mm})$ of shredded tyre waste can better be used for light weight fill behind the retaining walls (Amit Srivastava, 2014). Suresh and Murugaiyan carried out investigation of behavior of clayey soil stabilized with varying percentages $(0.5-10 \%)$ of coir fiber and Nano silica The study found that coir fiber and Nano particles influence the strength, permeability, swelling potential and resistance properties of soil ( $\mathbf{R}$ Suresh, 2018).

Ali et al concluded that colloidal Nano silica injection in soil can increase resistance to liquefaction and decreased permeability. In this research, sandy soil was mixed with silt in 5\%, $10 \%$, and $15 \%$ percent. Then, specimens in dry and saturated conditions were placed under the influence of Nano silica colloid. The results showed that geotechnical properties in the injected state increased compared to the non-injected state (Ali Kakavand 1, 2018).

\section{MATERIALS AND METHODS}

- Black Cotton Soil

Expansive soil (Black cotton soil) used in this study had been collected from a location in Sabarkantha district (Himatnagar-Vijapur Highway). The soil engineering properties were investigated by performing various tests in soil laboratory. 


\section{Available online at www.ijrat.org}

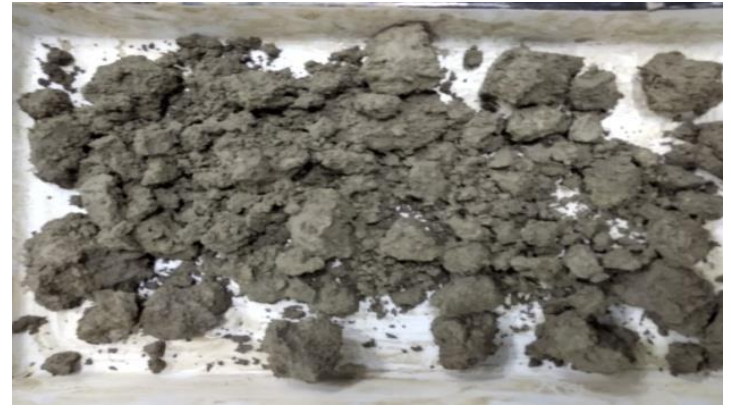

Figure 1: Soil sample

Table 1: Physical Properties of soil

\begin{tabular}{|c|c|}
\hline Physical Properties & Values \\
\hline Liquid limit & $43.2 \%$ \\
\hline Plastic limit & $24.08 \%$ \\
\hline Plasticity Index & $19.12 \%$ \\
\hline Shrinkage limit & $10.625 \%$ \\
\hline Specific Gravity & 2.453 \\
\hline Maximum dry density & $1.89 \mathrm{~g} / \mathrm{cc}$ \\
\hline $\begin{array}{c}\text { Optimum moisture } \\
\text { content }\end{array}$ & $14.15 \%$ \\
\hline CBR & $2.489 \%$ \\
\hline
\end{tabular}

\section{- Crumb Rubber Powder}

The particle size which has been used in the study is of 40 mesh passing ( $400 \mu$ passing), which has been collected from one of the industries producing crumb rubber powder in Daman.

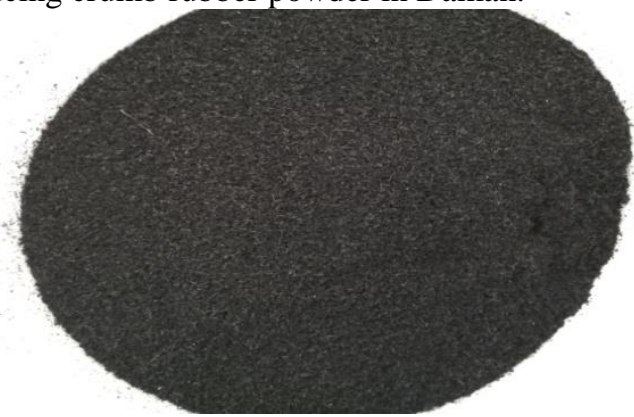

Figure 2: Crumb rubber of 40 meshes

- Nano-Silica

Table 2: Physical \& Chemical Properties

\begin{tabular}{|c|c|c|}
\hline Properties & Unit & $\begin{array}{c}\text { Typical } \\
\text { value }\end{array}$ \\
\hline $\begin{array}{c}\text { Specific } \\
\text { surface area }\end{array}$ & $\mathrm{m}^{2} / \mathrm{g}$ & $200 \pm 25$ \\
\hline $\begin{array}{c}\text { Average } \\
\text { particle size }\end{array}$ & $\mathrm{nm}$ & 12 \\
\hline $\begin{array}{c}\text { Tamped } \\
\text { Density }\end{array}$ & $\mathrm{g} / \mathrm{l}$ & Approx.50 \\
\hline Moisture & $\mathrm{wt.} \%$ & $\leq 1.5$ \\
\hline Ignition loss & $\mathrm{wt.} \%$ & $3.7-4.7$ \\
\hline $\mathrm{pH}$ & $\mathrm{wt} \%$ & $\geq 99.8$ \\
\hline $\begin{array}{c}\mathrm{SiO} 2^{-} \\
\text {content }\end{array}$ & $\mathrm{wt} \%$ & \\
\hline
\end{tabular}

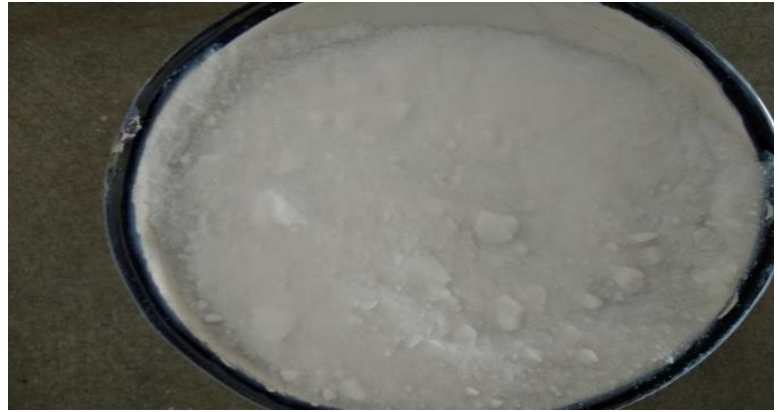

Figure 3: Nano-silica of 12nm size

\section{EXPERIMENTAL INVESTIGATION}

The experimental investigation was carried out in two different phases. One phase was to do experiments with the expansive soil without any additives and in second phase experiments were carried out with the addition of Crumb rubber powder and Nano-silica (additives) at varying percentage and finally blending both the additives with soil and performing various tests in soil laboratoty. Liquid and plastic limit of the treated and untreated soil were determined by the following standard procedure as per IS: 2720 Part V. Specific Gravity was determined by using pycnometer bottle method as per IS: 2720 Part III. Standard Proctor test was carried out as per IS: 2720 Part VII. And finally CBR test for soaked soil samples for 96 hours was performed as per IS: 2720 Part XVI for treated and untreated soil.

\section{RESULT AND CONCLUSION}

To know the effects of stabilizing materials on soil various tests were carried out with increasing percentage of crumb rubber powder $(2.5 \%, 5 \%$, $7.5 \%, 10 \%$ ) initially and it was found that at $5 \%$ CRP the CBR value was maximum. Then it was used as the optimum dosage to treat with the varying percentage of Nano-silica $(1 \%, 2 \%, 3 \%$, $4 \%)$.

Test conducted:

A. Plasticity characterstics

To investigate the effect of the stabilizing material on Plasticity characterstics, it is observed that on blending 5\% CRP with varying percentage of Nano-silica, the plasticity characterstics increases with the increase in Nano-silica.

B. Standard Proctor test

On increasing the percentage of Nano-silica in $5 \% \mathrm{CRP}$, it was observed that dry density decreases and optimum moisture content increases.

C. California Bearing ratio Test (CBR)

It was observed that CBR value of the stabilizers with expansive soil was maximum at the dosage of 5\% CRP and 2\% Nano-silica. And on further increase in the Nano-silica decreases the CBR value in soaked sample for four days. 
International Journal of Research in Advent Technology, Vol.7, No.3, March 2019 E-ISSN: 2321-9637

Available online at www.ijrat.org

\begin{tabular}{|l|l|l|l|l|l|l|}
\hline Sample & $\begin{array}{l}\text { Liquid limit } \\
(\%)\end{array}$ & $\begin{array}{l}\text { Plastic limit } \\
(\%)\end{array}$ & $\begin{array}{l}\text { Plasticity } \\
\text { index }(\%)\end{array}$ & $\begin{array}{l}\text { Optimum } \\
\text { moisture } \\
\text { content (\%) }\end{array}$ & $\begin{array}{l}\text { Maximum } \\
\text { Dry density } \\
(\%)\end{array}$ & $\begin{array}{l}\text { California } \\
\text { Bearing } \\
\text { ratio(CBR) } \\
(\%)\end{array}$ \\
\hline Collected soil & 43.20 & 24.08 & 19.12 & 14.15 & 1.89 & 2.48 \\
\hline $\begin{array}{l}5 \% \text { CRP + 1\% } \\
\text { Nano-silica }\end{array}$ & 44.83 & 23.44 & 21.39 & 13.51 & 1.84 & 4.37 \\
\hline $\begin{array}{l}5 \% \text { CRP + 2\% } \\
\text { Nano-silica }\end{array}$ & 47.34 & 26.42 & 20.92 & 13.92 & 1.81 & 6.14 \\
\hline $\begin{array}{l}5 \% \text { CRP + 3\% } \\
\text { Nano-silica }\end{array}$ & 49.17 & 28.11 & 21.06 & 14.63 & 1.53 & 5.37 \\
\hline $\begin{array}{l}5 \% \text { CRP + 4\% } \\
\text { Nano-silica }\end{array}$ & 52.2 & 33.39 & 18.90 & 15.27 & 1.41 & 4.73 \\
\hline
\end{tabular}

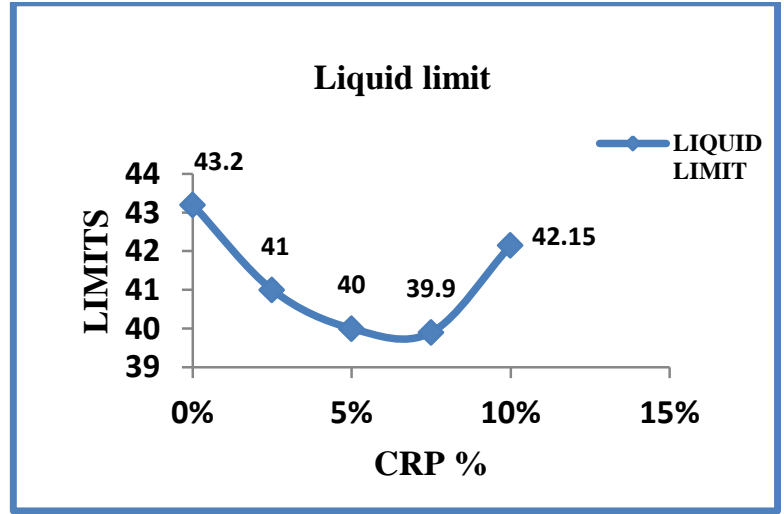

Figure 4: Liquid limit of soil with CRP

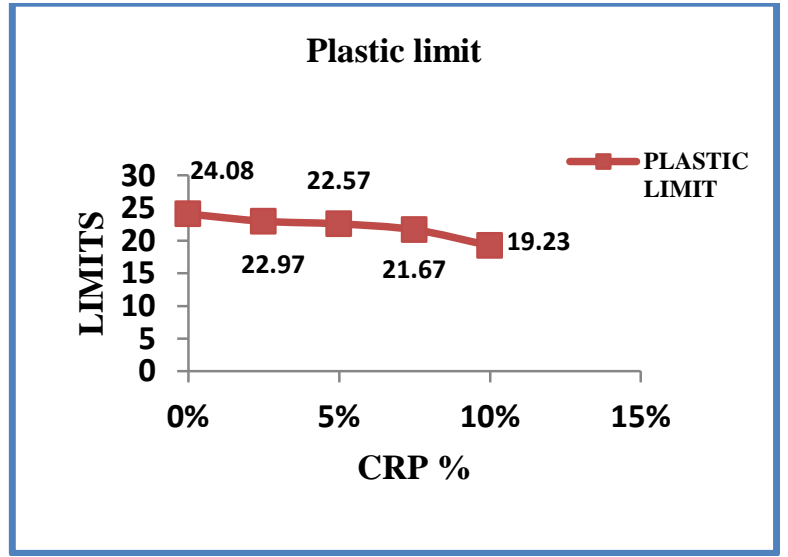

Figure 5: Plastic limit of soil with CRP

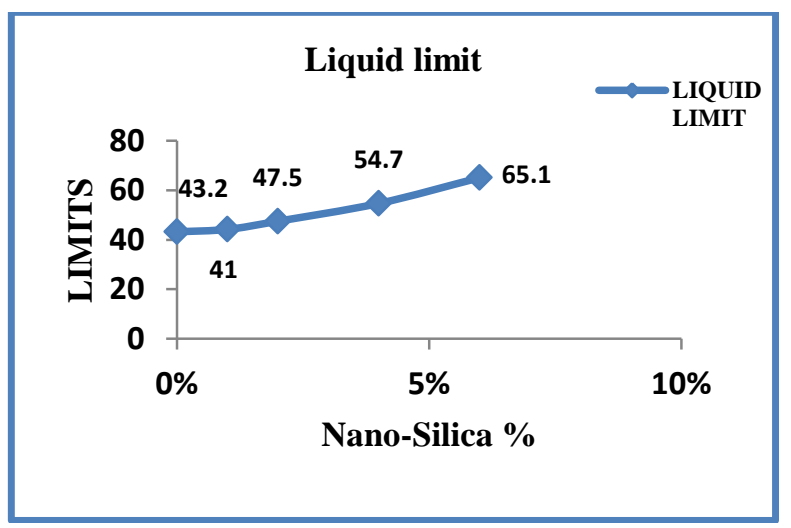

Figure 6: Liquid limit of soil with Nano-silica

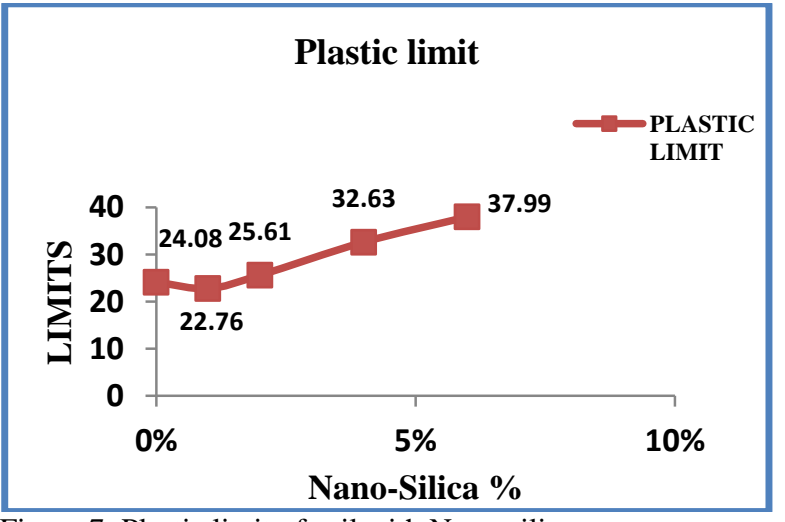

Figure 7: Plastic limit of soil with Nano-silica

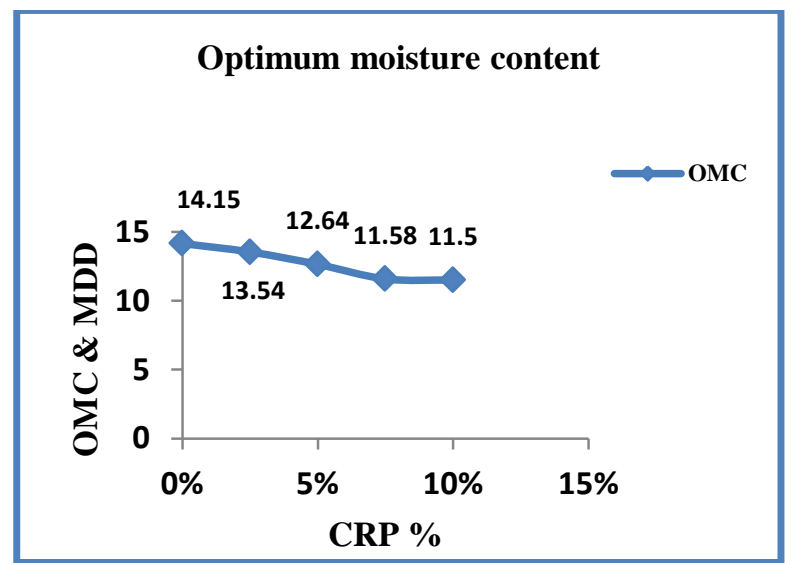

Figure 8: Optimum moisture content of soil with CRP

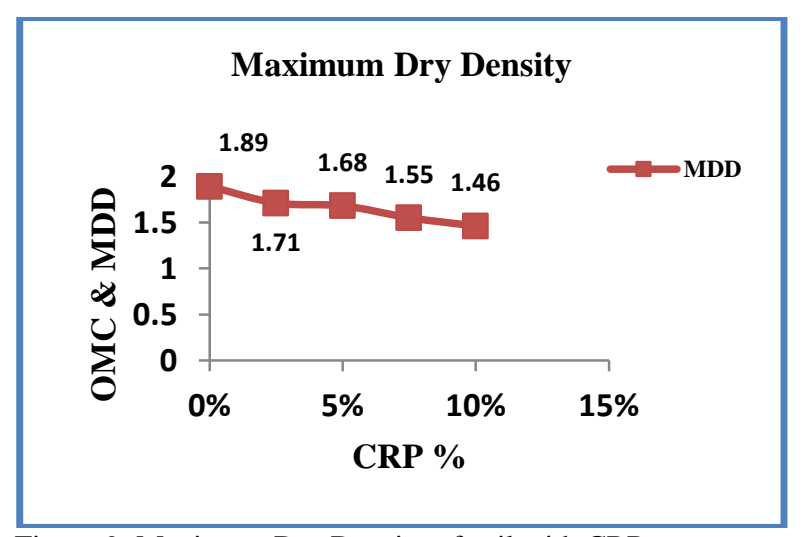

Figure 9: Maximum Dry Density of soil with CRP 
International Journal of Research in Advent Technology, Vol.7, No.3, March 2019

$$
\text { E-ISSN: 2321-9637 }
$$

Available online at www.ijrat.org

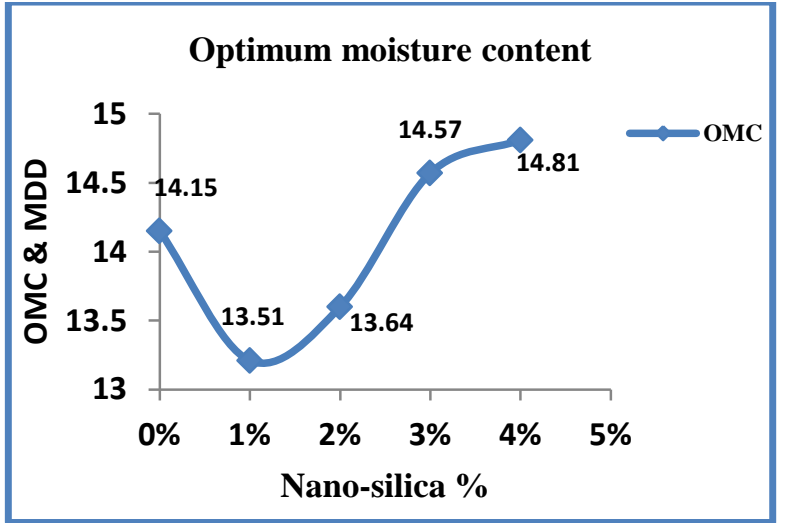

Figure 10: Optimum moisture content of soil with Nanosilica

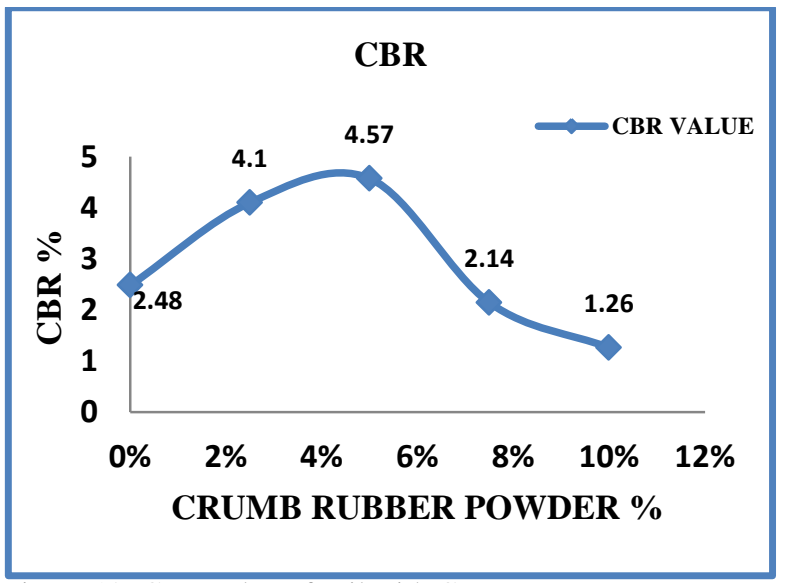

Figure 12: CBR value of soil with CRP

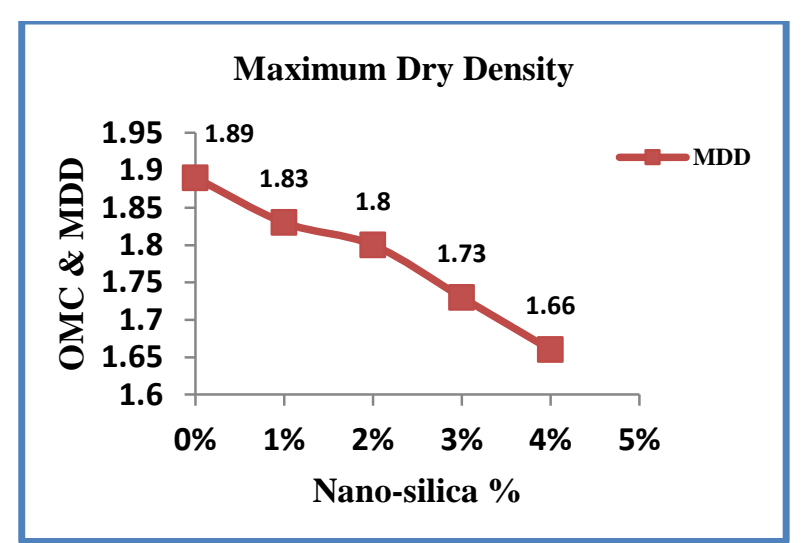

Figure 11: Maximum Dry Density of soil with Nano-silica

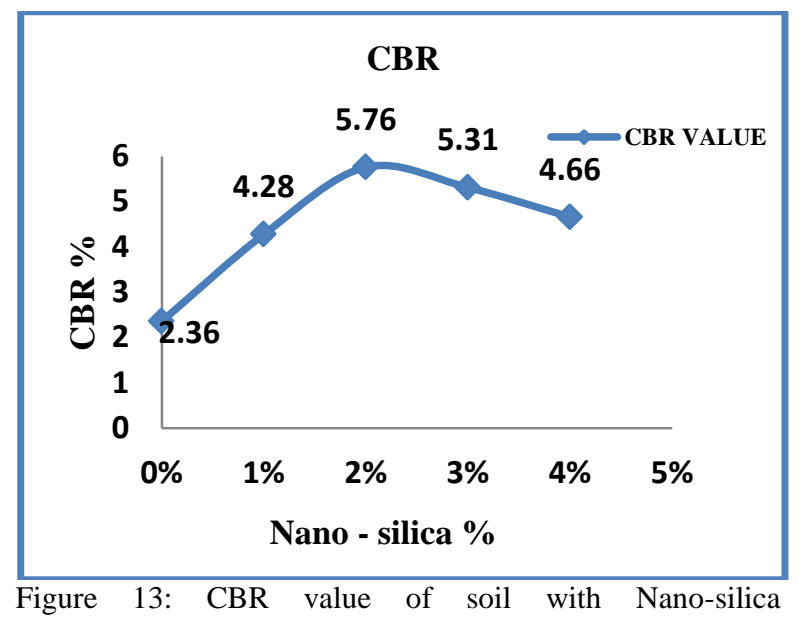

Experimental investigation on soil stabilization by blending Crumb rubber powder + Nano-silica + Soil

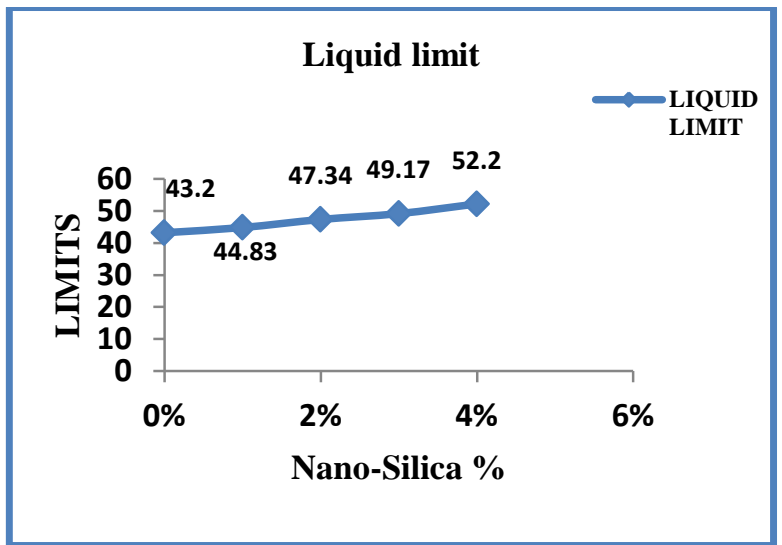

Figure 14: Liquid limit of soil with 5\% CRP + Nano-silica

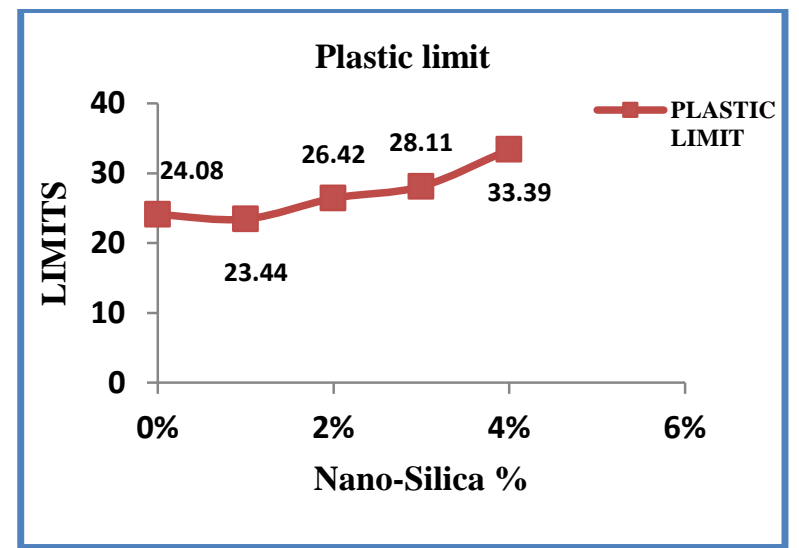

Figure 15: Plastic limit of soil with 5\% CRP + Nano-silica 
Available online at www.ijrat.org

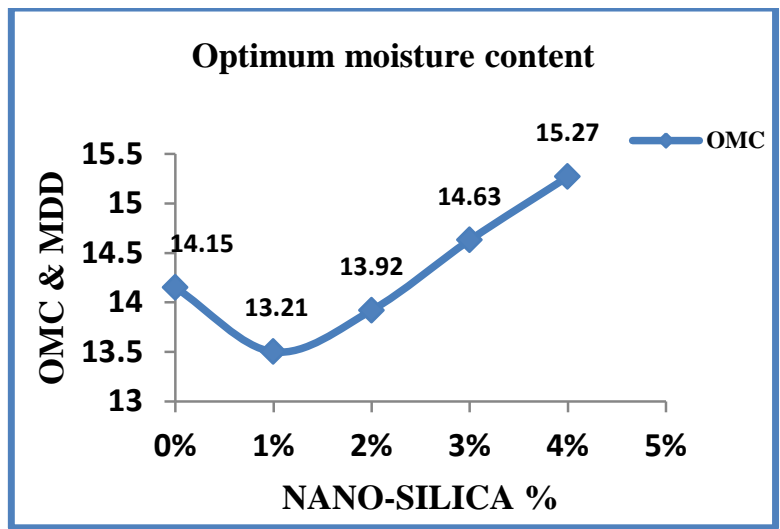

Figure 15: Optimum moisture content of soil with 5\% CRP

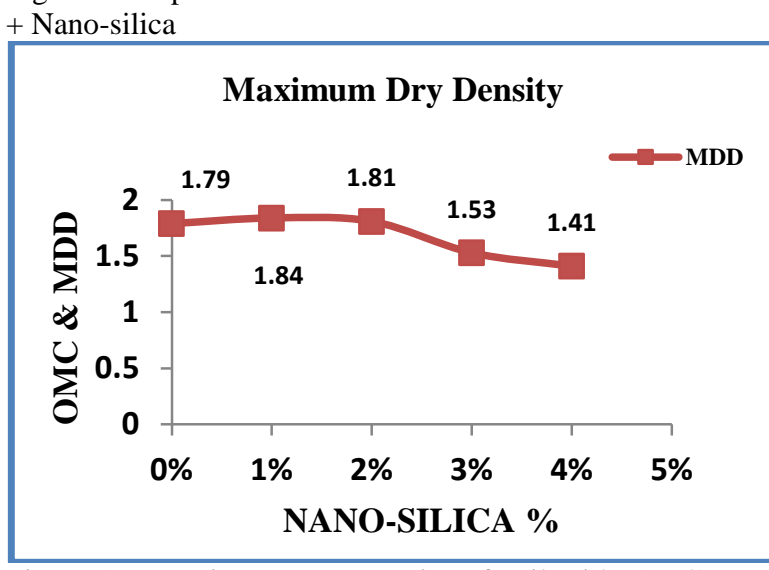

Figure 16: Maximum Dry Density of soil with 5\% CRP + Nano-silica

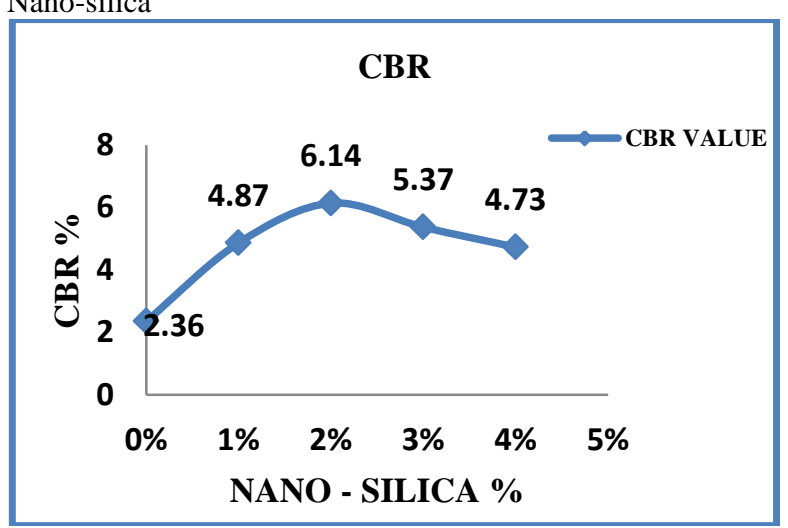

Figure 17: CBR value of soil with 5\% CRP + Nano-silica

\section{CONCLUSION}

Based on experiments carried out on soil with increasing percentage of Nano-silica $(1 \%, 2 \%, 3 \%$, $4 \%$ ) with $5 \%$ of crumb rubber powder as a constant the following observations had been concluded:

- CBR value is maximum with crumb rubber powder and soil at 5\% CRP and hence selected as the optimum dosage for the further study with Nano-silica.

- Optimum moisture content increases with increase in the percentage of Nano-silica at $5 \%$ CRP as constant.
- $\quad$ CBR value of soil when blended with 5\% CRP and $2 \%$ Nano-silica was found maximum as $6.14 \%$, which is two times greater than the CBR value of untreated Black soil.

- So, it can be concluded that incorporation of 5\% Crumb rubber Powder and 2\% Nano-silica can increase the CBR value and can help in stabilizing the soil.

\section{ACKNOWLEDGMENT}

I would like to express my sincere gratitude to Dr. H. R. Varia for initial spark and subsequent valuable guidance in my research work. My special gratitude to my classmates for their meaningful support for their kind helps at different levels. Special thanks to my college for giving me the valuable knowledge. Above all I am thankful to almighty God for everything.

\section{REFERENCES}

[1] Ali K. and Dabiri R. (2018) "Experimental study of applying colloidal Nano Silica in improving sand-silt mixtures", International Journal of nano dimensions.

[2] Kokila L., Bhavithra G., Hemapriya V., Iniya C., Madhunigga P. (2017), "Experimental Investigation on Soil Stabilisation Using Rubber Crumbs on Expansive Soil", World Journal of Research and Review (WJRR).

[3] Srivastava A., Pandey S and Rana J. (2014) "Use of shredded tyre waste in improving the geotechnical properties of expansive black cotton soil", Geomechanics and Geoengineering: an International Journal.

[4] SriVasavi1 B., Prasad D.S.V., Prasad A.C.S.V. (2016), "Stabilization of expansive soil using crumb rubber powder and cement", IJIRT.

[5] Suresh R., Murugaiyan V. (2018), "Improvement of clay soil using natural fibers and nano silica: a Review", Indian journal of scientific research.

[6] Yadav J.S., Tiwari S.K. (2017), “Assessment of geotechnical properties of uncemented/cemented clayey soil incorporated with waste crumb rubber", Journal of Materials and Engineering structures. 